\title{
Studying as a parent: a handbook for success
}

A book review of Owton, H. (2014) Studying as a parent: a handbook for success. Basingstoke: Palgrave Macmillan.

\author{
Marie Nadia Jasim \\ St George's, University of London, UK
}

\section{Overview}

As more establishments charge the top tuition fee of $£ 9000$, we have seen an increased drive to widen participation into higher education. The Office for Fair Access (OFFA) reports that 172 universities and colleges have received approval to charge the top fee in academic year 2015/16 (OFFA, 2014a). OFFA requires all establishments charging this amount to have an Access Agreement (OFFA, 2014b), and are now requesting that universities research and evaluate the support they provide (OFFA, 2014c). With rapidlygrowing, evidence-based support services on hand, how useful is a handbook for student parents?

The Higher Education Statistics Agency (HESA) does not currently collect data regarding the number of students who balance their studies alongside raising a family (Equality Challenge Unit, 2010). Despite a growing mature student body, equating to approximately a third of all first-degree undergraduates (National Union of Students, 2012), there has been no real incentive for universities to document the number of student parents at their establishment, nor provide targeted support to assist them in their studies. This easy-toread handbook aims to encourage student parents to enter higher education, and points to where they can access support. It consists of accurate and up-to-date information intertwined with honest personal advice. True understanding comes from the writer having completed an undergraduate degree, a Masters, and later a $\mathrm{PhD}$, whilst being a single mother to her young daughter Ellie. Now a university lecturer, Owton appears passionate 
about ensuring that student parents are equipped with the necessary knowledge to flourish at university.

\section{Layout and structure}

The book is logically divided into four main sections with information on Access courses; the support available to student parents; managing a balanced lifestyle and finally advice on points to consider after graduation. Information can be easily located with help of the index.

Owton blends relevant factual information with her own personal stories, creating a conversational tone throughout. In separate boxes, she also includes quotes from other student parents regarding their individual experiences. These aid to break up the main body of text, but frustratingly have not been used to great effect. In most instances, the main text repeats the quote beside it. A strength of using multiple insights should be that they reflect the diversity of student parent experiences. Additionally, the excerpts are occasionally used again in later chapters, which can be unsatisfying when reading the handbook from start to end. Incorporating the views of twenty-three student parents should have been an asset to the book, and it is unfortunate that it has not been used successfully. The text is otherwise carefully researched and well-referenced throughout, with an excellent bibliography directing the reader to further available articles and resources.

\section{Content}

The prologue consists of a typical diary entry of a student parent: a day in the life of the author as an undergraduate at the University of Winchester. From the start we are met with a very honest and personal account of what it is like to be a studying parent. For readers yet to embark on this journey, it very accurately details the typical ups and downs, the realities of raising children on a tight budget, and the immense background preparation involved. These pages would also be beneficial for staff involved in supporting student parents. It is so well-described and all-encompassing that it would assist any reader to empathise and understand the typical day-to-day experiences of student parents. 
The handbook begins by addressing Access courses for parents considering university despite having left school without the necessary qualifications. The section details the application process, course structure, funding issues and the reality of balancing family commitments with this type of course. The information is thorough and covers many of the questions a potential student parent may not have considered asking. Particularly useful is the advice on what to consider when choosing a university (the cost of relocating with a family, the travel time involved in commuting between the university and local schools, and how childcare will work around placements). Such questions are seldom answered in university prospectuses, and so the book provides checklists to assist the reader in making wise choices. Again, this awareness would be invaluable for university staff in addition to the target audience. Owton is encouraging, addressing a common concern that many mature students have - that they may not be 'clever enough' to return to education. Although this initially comes across as reassuring, for some readers it may come across as patronising if they did not need consistent urging to 'be confident in [their] abilities'. The student quotes used in this section are taken entirely from parents in Northampton, giving the impression that the interviewees may have attended the same Access course. Again, this is a disappointing use of the student parent interviews. Geographically varied sources would have created a more rounded impression of how Access courses are for those with families. A more inclusive approach is achieved in the second section of the book, which looks at some of the difficulties faced by parents passing through the higher education 'system'. Owton successfully identifies different types of student parent and the various challenges each may face. She should be commended for her recognition of student parents covering a wide spectrum of people, and makes a point to include advice for the minority subgroups of: younger parents, lone parents, LGBT parents and disabled parents. Such acknowledgement is often lacking in student support services, and is a valuable part of the book.

The second and third sections of the book comprise the most essential information regarding the support available to student parents. It is excellently written and forms the book's vital core. The information is relevant and concise, covering university support provisions; financial assistance; childcare provider options and all relevant and up-to-date legislation. The strength of the writing comes not only from its comprehensiveness, but the tone in which it is delivered. It does not disguise the 'disempowering' nature of the benefits system, the 'lack of expertise' of student finance advisors, nor the 'lack of support from tutors'. It is frank, truthful, and equips the reader with an awareness of what to expect 
during their course. In doing so, Owton has provided precisely the information a student parent needs; which support systems are reliable and where they will need to remain independently driven and strong. She remains positive throughout, reminding the reader to be 'assertive' and to keep their 'chin up'.

Owton has attempted to be as comprehensive as possible, with advice extending to cover the importance of a social circle, healthy eating, and even maintaining good posture! Although attempts have evidently been made to include relevant information for all types of student parent, overall the text seems geared towards those from the same background as herself, namely single parents on a low income. Although the book recognises that pregnancy is a 'vulnerable time for relationships', it fails to mention how family bonds can become strained when there is only one breadwinner left to support the family plus their partner's studies. A large proportion of student parents leave their lives as a full-time parent or employee to return to education and recognition of the colossal changes in their household dynamics is absent from the book. It is regrettable that the text focuses on the childcare element of being a student parent, but overlooks that many parents are raising children in a partnership.

A key theme for the author is 'managing identities', and the conflicts in being a driven student as well as a committed mother. Studying alongside non-parents, it can be isolating if no one understands the blend of pride and guilt that comes with the journey. In acknowledging these anxieties, the handbook serves not only as an information guide but an empathetic friend. Owton particularly describes and promotes the setting up of student parent groups; an incredibly effective way of establishing an understanding social circle. This is illustrious of how the information in the book is mostly sourced from personal experience, and is currently not found in any other publication.

\section{Conclusion}

'Studying as a parent a handbook for success' is an accessible paperback containing a wealth of information and honest advice, delivered with uplifting optimism. It is targeted at parents considering higher education as well as those already in attendance. It is very current, with up-to-date material on existing guidelines and legislation. To continue to be relevant, the content will need to be regularly updated. Despite publication in September 
2014, it already requires revision to include the new changes related to shared parental leave that take effect from April 2015. Beyond the target audience, this book is recommended to all staff working with student parents. It successfully details the challenges that this group of students face and broadly covers the avenues of available support.

The author should be applauded for her efforts to compile and simplify the maze of laws and financial systems that are necessary for this group of students to be aware of. It is the only available publication to cover these topics and this is a good reason for it to be made available to students. Future editions could be improved through better use of multiple student parent insights to reflect the diversity of student parent experience. At present, it is written from the heart of a woman who knows the struggles of being a studying parent, battling unaware of the available support. Indeed:

Knowing support is there, even if you don't access it, can be enough sometimes.

It is regrettable that this book is so necessary but this will remain the case until universities address more comprehensively the issues it raises, and ensure that the students who need it have access to this information.

\section{References}

BIS (2011) Higher education: students at the heart of the system, Department for Business Innovation and Skills (BIS) White Paper, June. Available at: https://www.gov.uk/government/uploads/system/uploads/attachment_data/file/3138 4/11-944-higher-education-students-at-heart-of-system.pdf. (Accessed: 2 October 2014).

Equality Challenge Unit (2010) 'Student pregnancy and maternity: implications for higher education institutions'. Available at: http://www.ecu.ac.uk/publications/studentpregnancy-and-maternity (Accessed: 15 December 2014). 
National Union of Students (2012) Never too late to Learn. Available at:

http://www.nus.org.uk/PageFiles/12238/2012 NUS millionplus Never Too Late T o Learn.pdf (Accessed: 15 December 2014).

Office for Fair Access (2014a) Access agreements for 2015-16: key statistics and analysis. Available at: http://www.offa.org.uk/wp-content/uploads/2014/07/Accessagreements-for-2015-16-key-statistics-and-analysis.pdf (Accessed: 15 December 2014).

The Office for Fair Access (2014b) How to produce an access agreement for 2015-16. Available at: http://www.offa.org.uk/guidance-notes/how-to-produce-an-accessagreement-for-2015-16 (Accessed: 15 December 2014).

The Office for Fair Access (2014c) Call for evidence: impact of financial support. Available at: http://www.offa.org.uk/publications/call-for-evidence-impact-of-financial-support (Accessed: 15 December 2014).

\section{Author details}

Marie Nadia Jasim is a mature student studying Medicine at St George's, University of London. She is in her second year as president of the university's Student Parent Association. 